\title{
Factors Influencing the Diversification of Mating Behavior of
}

\section{Animals}

\section{Afzal $\mathrm{S}^{1,2 *}$, Shah $\mathrm{SS}^{1,2}$, Afzal T11, Javed RZ1 ${ }^{1}$, Batool F1, Salamat $\mathrm{S}^{1}$ and}

Raza $A^{1}$

${ }^{1}$ Department of zoology, university of Narowal, Pakistan

${ }^{2}$ Department of zoology, university of Punjab, Pakistan

*Corresponding author: Sabila Afzal, Department of zoology, University of Punjab, Pakistan, Email:

\section{Review Article \\ Volume 2 Issue 2}

Received Date: January 28, 2019

Published Date: April 24, 2019

DOI: $10.23880 /$ izab- 16000145

Sabilasyed15@hotmail.com

\begin{abstract}
"Mating system" of a population refers to the general behavioral strategy employed in obtaining mates. In most of them one sex is more philopatric than the other. Reproductive enhancement through increased access to mates or resources and the avoidance of inbreeding are important in promoting sex differences in dispersal. In birds it is usually females which disperse more than males; in mammals it is usually males which disperse more than females. It is argued that the direction of the sex bias is a consequence of the type of mating system. Philopatry will favor the evolution of cooperative traits between members of the sedentary sex. It includes monogamy, Polygyny, polyandry and promiscuity. As an evolutionary strategy, mating systems have some "flexibility". The existence of extra-pair copulation shows that mating systems identified on the basis of behavioral observations may not accord with actual breeding systems as determined by genetic analysis. Mating systems influence the effectiveness of the contraceptive control of pest animals. This method of control is most effective in monogamous and polygamous species. Factors effecting mating system include parental care, territory, spatial distribution of mate, sexual selection, sex difference in life history and temporal variability in sexual receptivity etc. Environmental factors also influence mating system such as temperature.
\end{abstract}

Keywords: Mating System; Sexual Selection; Breeding Success; Mate Selection

\section{Introduction}

Mating occur between two opposite sex that plays a crucial role for the transfer of genes from one generation to next generation. Mating system is important for the basic difference of gene pool of various population and social behavior [1].

Animal mating system is highly diverse and has generally been classified as monogamous and polygamous. Polygamy is further classified into three categories polygyny, polyandry and poly gynandry. Mate choice by males and females are most significant in mating. Males select females on the basis of their morphology and parental care. In many species selection of mate by females is more significant than male [2]. Female selects male on the basis of size, fitness, territory, parental care, sperm production and resources availability. In males genetic variations are more diverse than females [3]. If only few members of a species will mate it leads less variations and low rate of population rather than if all 
member mate. It cause more diversity and increase in number of population [4].

\section{Mating System}

The term mating system refers to the way in which individuals are grouped in relation to [5]. Mating system causes evolution by changing the genetic structure and diversity of population [6]. Mating system influences the fitness of mate, size, territory, sperm production, and competition on these basis population is maintained and natural selection occur [7,8]. Mating system demonstrated all the methods and characteristics that help to acquire mate [5] (Table 1).

\begin{tabular}{|c|l|}
\hline Monogamy & Only one mate required for breeding for one season \\
\hline Polygyny & $\begin{array}{l}\text { Male copulate with many females in a breading season while female has only one } \\
\text { mate. }\end{array}$ \\
\hline Polygamy & Both sexes have random mating by having equal success. \\
\hline Polyandry & A single female mate with different males to enhance genetic variations. \\
\hline Polyandrogany & $\begin{array}{l}\text { In this type female mostly select their mate while both sexes have more than one } \\
\text { mate. }\end{array}$ \\
\hline Polygynandry & $\begin{array}{l}\text { This type male mostly select their mate while both sexes have more than one } \\
\text { mate. }\end{array}$ \\
\hline Promiscuity & $\begin{array}{l}\text { It refers to all the copulation in a mating system when there is no pair bond. Only } \\
\text { partners meet for a short time [9]. }\end{array}$ \\
\hline
\end{tabular}

Here modified definitions are taken from hope Klug [5].

Table 1: Variations in animals mating behavior.

\section{Classification of Mating System}

Classification expanded by demonstrating the pair bond duration resources used defense and parental care [10]. There are many ways to classify animal mating system. If basic informative data is absent then utilize the number of mate in which behavioral aspects are not studied. Meanwhile behavioral data is present then mating system is classified on the basis of capabilities of each sex to monopolies the opposite sex and critical resources and time period of paring bonding between mates and parental care [10-12].

\section{Monogamy}

When one sex has only one mate for a specified breeding season, is called Monogamy [5].

\section{Black Legged Kittiwake}

Monogamy in which only one male and one female mate and produce their offspring's. Monogamy occurs in most of birds. The best example of monogamy is black kittiwake. The best example for monogamy is black legged kittiwake. Only one male and one female is mate to produce two or three offspring's. They lives in groups and colonies in seaweeds and dense vegetation. Male and female both provide parental care to young ones. Males tend to be larger than female [13]. By seeing behavior and genetic of black legged kittiwake it revealed that they mate with only one partner because they are monogamous. Male and female mate on the base of size. Usually the larger males are selected for mating because larger size male provide more defense and high quality of sperms during copulation. Female copulate 2 weeks ago before lying eggs and tend to retain the sperm which resulted copulation occur soon. The offspring's which are produced by fertilization of egg with older sperm are poor than younger sperm [14]. Black legged kittiwake are best for monogamous because they have potential for extra pair copulation. Both male and female provide parental care and territory to their young ones. Moreover female prefer the younger sperm for mating than older and large size males.

\section{Polygyny}

When female has a single mate and male has many mates during breeding season is called Polygyny [5].

\section{Elephant Seals}

Elephant seals are larger mammals. The two more close species of elephant seals are the northern elephant seal, Miroungaangustirostris, and the southern elephant seal, Mirounga leonine. In Polygyny one male mate with many females. One male can mate with 9-200 females. The females come to shallow and mate with males and then move back to seas. After 11 month of pregnancy they come to shore and give birth to young ones. Similarly other females come give birth to offspring's and move 


\section{International Journal of Zoology and Animal Biology}

back to seas. Males at shore they mate with many females at shore. They provide defense, territory to their young ones. They provide parental care and look after the offspring's at shore [15]. Male can mate with different females because estrus cycle varying in different females in different seasons. They mate on the base of large size because large size male show more fitness, copulation strategies, sperm production of good quality [15]. Elephant seals best example of Polygyny because in elephant seals one male can mate with many females, male provide more defense and territory to offspring's and show dominancy.

\section{Polyandry}

When female has many mates and male has only one mate during specified time period (breeding season) is called Polyandry [5].

\section{Honey Bees and Ants}

Fitness gain fitness by polyandry [16]. One female mate with multiple male during one breeding season. This does not increase number of off springs to attain fertilization with high quality sperm (younger and long). Mating with single male may threaten death of young offspring before weaning [17]. Polyandry frequently occurs in mammals but rare in birds $(>10 \%)$. Honey bee is the best example of polyandry. Queen honeybee mate with many drones in hives and produce new generation. Polyandry is also seen in ants because queen ant has the capability to select sperm for fertilization. Benefits for female allowing fertilization assurance, provision of resources and parental care for their off springs. House mice have shown in direct genetic benefits where female have increased off springs surviving through multiple mating showing that practicing polyandry mating results in an increase in off springs viability [18].

\section{Polygamy}

When both sexes have more than one mate this condition is called Polygamy [5].

\section{Grouse Mating System}

Polygamy is very significant for both male and female. Polygamy is very rare in birds as quail (other birds also include) show monogamy. Polygamy is also common in mammals. Polygamy also occurs in many grouse including North America grassland species and in peafowl. Dancing grouse define territory around their nests and produce different sound to attract females. Females round their nests and copulate with male. Sometimes in groups hierarchy formed and dominant male copulate with many females in his territory [19].

\section{Factors}

There are many factors that change the structure of mating system. These factors include territory defense, distribution of resources, distribution of mates in space, sexual selection, sex differences in life history and temporal variability. If mates in resources are less in space monogamy occurs. Moreover, excessive resources and mate availability cause polygamy [11].

Mating system is directly affected by many factor such as spatial and temporal distribution of sexually receptive males and females, resource availability and distribution, male and female life history, sexual selection, parental care and territory [5].

\section{Spatial Distribution of Resources and Mates}

Male reproductive success depends upon female availability while female reproductive success is depending upon resources [3]. As female are attracted by resources so it is difficult for a single male to mate more than one female. Under these circumstances male define territory and achieve monogamy. If plenty resources are available and individuals by utilizing them attract the opposite sex that are in search of these resources [11]. Distribution of resources in space in the form of patches enhances the potential of male to attain polygamy. Plenty of resources will also start competition which decreases the potential for polygamy. It is usually discovered in some species that female show aggression for food while male show aggression for food and mate in variable degree $[20,21]$. In some species of lizard's female lives in that area where plenty of food is available and growth rate relates with rainfall. Male grows slowly in nonwatered areas than the watered areas but not relates with rainfall [20].

Males find females for mating. If females are solitary and disperse in an area males travel long distance between mating, thus rovers male develop. If females are solitary and close, covering smaller area males develop territory against intruding males. Rover's polygynous behavior depends upon their fitness and the intensity of mates. Sometimes permanent territory not happened usually when female's group move continuously in search of resources. During movement males travel along with group and defend females in a harem system (e.g Baboons). 


\section{International Journal of Zoology and Animal Biology}

In mostly avian resources directly affect mating system. Easily resources availability exhibit Polygyny. But during shortage of resources monogyny occur. When a male monopolize resources, it enhance reproductive success and the intensity of reproduction. Female distribution in an area depends upon distribution of resources (e.g Beetles).

\section{Parental Care}

Parental care has great importance in mating behavior. Parental care is the important effect in mating system. Both individuals provide parental care to off springs.

If the caring individual is unavailable then the sexes for mating become rare in population. Male plays a crucial role in mating system of many species. In most of birds male provide the parental care to their young ones. Most of the males are selected on the base of their parental care. Strategies for parental care vary from species to species in animal taxa which depend upon the duration and number of offspring [22]. Parental care prevents mating and leads to less number of caring parents in population [23]. Individuals involved in parental care will be receptive sexually [24].

\section{Temporal Variability in Sexual Receptivity}

In addition to scattered in the space, the availability of the mate may change over time. Potential of males to monopolize mate decreases if number of receptive female increases in a given time period [11]. If mostly females are not receptive in same time then male can mate with different females and their potential towards Polygamy increases [11]. If receptivity varies with respect to time there are many aspects behind it such as parental care and production of gametes.

\section{Sexual Selection}

It is the process by which opposite sex get the limited availability of their mates [25]. In sexual selection the availability of limited mates tends to create the sense of competition among the opposite mates $[10,11]$.

Sexual selection can affect the entire mating system. The most important degree of sexual selection is, it is the single factor that determines mating system. Some of very popular papers have focused on the basic role of sexual selection in finding dynamics of mating system. Selection makes many species go to extreme length for sex. For example Peacocks maintain elaborate tails and elephants seals fight over territories, fruit flies perform dances and some species deliver persuasive gifts.

\section{Sex Differences in Life History}

Receptive male and female are affected by the rate of maturation and their dispersal in space. Parental care and availability of mate have strong effect on mating system. the ratio of male and female that currently available for mating influence the mating system [23] operational ratio adult density $[11,26]$.

\section{Evolutional and Ecological Perceptive for Ecosystem}

Mating system influence evolution and ecological phenomena of selection when competition starts among mates and result in female harassment. For mating individual select special traits as large body size increase fighting ability alternative mating tactics and pass their sperm. In 1995 Harcourt founded fluctuations that explain testis size in primates. Primates having larger testis will mate single female.

In a community, when only few males mate, they will reduction of population. Other while, all individual mate. Effective population has strong impact on evolution [4].

To enhance the species efforts for mating and reproduction have great importance. Opportunities and efforts are affected by three main factors such as boundaries for two opposite sex in a taxa, individual age and size difference and ecological conditions. Polygyny occurs when male has great opportunity for sex and monogamy leads when more parental care required for off springs Verh, et al. (1994).

\section{Temperature (Environmental Factor)}

Temperature also affects the mating system of animals. It changes the behavior of animals as communication signals between mates. Temperature effect on sound as in the example of bee female selection depends upon thorax vibrations and odor of male Taina Conrad, et al. (2017).

\section{Conclusion}

Animal Mating system has great importance for animals to survival their genes that transfer in next generation. Mating system varies due to important factors such as parental care, mate availability, distribution of resources in apace, mates life history, territory, defense and competition. These factors directly affect mating system as dispersal of mates and resources leads polygyny, parental care leads monogamy and ecology has great importance for mating in taxa to produce off springs. Recent studies have increased our knowledge about 


\section{International Journal of Zoology and Animal Biology}

mating behavior of animals. But there is need to more explanation of factors that directly or indirectly affecting mating system because, as we know that how a mating system affect by factors in an ecosystem.

\section{References}

1. Sinervo B, Robert A (2016) Mating system.

2. Jones AG, Mobley KB, (2009) Environmental, demographic, and genetic mating system variation among five geographically distinct dusky pipefish (Syngnathus floridae) populations. Mol Ecol 18(7): 1476-1490.

3. Bateman AJ (1948) Intra-sexual selection in Drosophila. Heredity 2(3): 349-368.

4. Nunney L (1993) The influence of mating system and overlapping generations on effective population size. Evolution 47(5): 1329-1341.

5. Klug H (2011) Animal Mating Systems.

6. Darwin C (1871) The Descent of Man, and Selection in Relation to Sex. John Murray, London.

7. Agren J, Schemske W (1993) outcrossing rate and interbreeding depression in two annual monoecious herbs, begonia hirsute and B. SEMIOVATA. Evolution 47(1): 125-135.

8. Noël E, Jarne P, Glémin S, MacKenzie A, Segard A, et al. (2017) Experimental Evidence for the Negative Effects of Self-Fertilization on the Adaptive Potential of Populations. Curr Biol 27(2): 237-242.

9. Davies A (1991) Book Reviews. Journal of Language and Psychology 10(4): 292-295.

10. Shuster SM, Wade MJ (2003) Mating Systems and Strategis. pp: 552.

11. Emlen ST, Oring LW (1977) Ecology, sexual selection and the evolution of mating systems. Science 197(4300): 215-223.

12. Davies NB (1991) Mating systems. In: Krebs JR, Davies NB, (Eds.), Behavioural Ecology: An Evolutionary Approach, $3^{\text {rd }}$ (Edn.), Oxford: Blackwell Scientific Publications, pp: 263-294.
13. Helfenstein F, Danchin E, Wagner RH (2004) Assortative mating and sexual size dimorphism in black-legged kittiwakes. Waterbirds 27(3): 350-354.

14. Wagner RH, Helfenstein F, Danchin E (2004) Female choice of young sperm in a genetically monogamous bird. Proceedings of the Royal Society of London 271(S1): S134-S137.

15. Hoelzel AR, Le Boeuf BJ, Reiter J, Campagna C (1999) Alpha-male paternity in elephant seals. Behavioral Ecology and Sociobiology 46(5): 298-306.

16. Keil A, Sachser A (1998) Reproductive Benefits from Female Promiscuous Mating in a Small Mammal. Ethology 104(11): 897-903.

17. Alcocok J (2005) The scramble competition mating system of the sphecid was Palmodes praestans (Kohl). $39(30)$.

18. Margaret J, Couvillon, Hughes WOH, Perez-Sato JA, Martin SJ, et al. (2010) Sexual selection in honey bees: colony variation and the importance of size in male mating success. Behavioral Ethology 21(3): 520-252.

19. James F, Witten berger (1979) The Evolution of Mating Systems in Birds and Mammals. Social Behavior and Communication pp: 271-349.

20. Stamps J, Reid ML (1997) Female Mate Choice Tactics in A Resource-Based Mating System: Field Tests of Alternative Models. Am Nat 150(1): 98-121.

21. Vinegar MB (1975) Comparative aggression in Sceloporus virgatus, S. undulatus consobrinus, and S. u. tristichus (Sauria: Iguanidae) 23(2): 279-286.

22. Clutton Brock TH (1991) The Evolution of Parental Care. Princeton University Press, USA.

23. Kokko H, Jennions MJ (2008) Parental investment, sexual selection and sex ratios. J Evol Biol 21: 919948.

24. Stiver K, Alonzo SH (2009) Parental and mating effort: is there necessarily a trade-off?. Ethology 115(12): 1101-1126.

25. Kokko H, Rankin DJ (2006) Lonely hearts or sex in the city? Density-dependent effects in mating systems. Philosophical Transactions of the Royal Society of London B 361(1466): 319-334. 


\section{International Journal of Zoology and Animal Biology}

26. Conrad T, Stöcker C, Ayasse M (2017) The effect of temperature on male mating signals and female choice in the red mason bee, Osmia bicornis (L.). Ecology \& evaluation 7(21): 8966-8975. 